\title{
IMPLEMENTATION OF FLEXIBILITY STRATEGY ON AGRICULTURAL COMMODITY FINANCING WITH WAREHOUSE RECEIPT SYSTEM
}

\author{
Karmex Siadari*), M.Syamsul Maarif*), Bustanul Arifin**), Zulkifli Rangkuti***) \\ ${ }^{*}$ School of Business, IPB University \\ Jl. Pajajaran, Bogor 16151, Indonesia \\ ${ }^{* *}$ Department of Agribusiness, Faculty of Agriculture, University of Lampung \\ J1. Prof. Dr. Ir. Sumantri Brojonegoro No.1, Bandar Lampung, Lampung 35141, Indonesia \\ $\left.{ }^{* * *}\right)$ Management IMMI Jakarta \\ Jl. Tanjung Barat No.11 South Jakarta, 12510, Indonesia.
}

\begin{abstract}
The implementation of warehouse receipt financing system for agriculture commodities has not been successfully developed in Indonesia, some constraints are hindering the system to grow. Flexibility strategy is conceptually applicable to minimize gaps in the system to its environment. This research was conducted to determine an adaptive warehouse receipt financing system using strategic flexibility. The research was carried out by ways in-depth interviews and focus group discussions with respondents with knowledge of or experience in warehouse receipt financing systems for commodities such as coffee, pepper, rice and maize. Analysis was done using Soft System Methodology (SSM) and Interpretive Structural Model (ISM) analysis to define conceptual models of flexibility strategy applied in warehouse receipt financing systems. The research findings, flexibility strategy is applicable in the warehouse receipt financing system: applying resource flexibility on input side to select the most efficient material to develop the product, applying resource and coordination flexibility in internal process to optimize internal processing, applying internal resources and coordinating flexibility on output distribution to expand the market and applying coordination flexibility to respond external condition. However, applying a flexibility strategy to respond externally was found to be the most suitable to adapt agriculture commodities financing on warehouse receipt system to its environment.
\end{abstract}

Keywords: agricultural commodities, financing constraints, flexibility strategy, warehouse receipt system

\begin{abstract}
Abstrak: Pembiayaan sistem resi gudang secara konsep dapat diterapkan untuk membiayai komoditas pertanian. Walaupun hingga belangkangan ini masih menghadapi kendala yang menghalangi untuk berkembang di Indonesia. Strategi fleksibilitas secara konseptual dapat meminimalkan kesenjangan sistem dengan lingkungannya. Penelitian ini dilakukan untuk menentukan sistem pembiayaan resi gudang yang adaptif dengan menggunakan strategis fleksibilitas. Penelitian dilakukan dengan wawancara mendalam dan diskusi fokus grup kepada kelompok responden yang memiliki pengetahuan atau pengalaman pada pembiayaan sistem resi gudang untuk komoditas seperti kopi, lada, beras dan jagung. Analisis dilakukan dengan menggunakan Soft System Methodology (SSM) dan Interpretive Structural Model (ISM) untuk menentukan model konseptual strategi fleksibilitas yang dapat diterapkan pada sistem pembiayaan resi gudang. Hasil penelitian menunjukkan bahwa strategi fleksibilitas dapat diterapkan dalam sistem pembiayaan resi gudang: menerapkan fleksibilitas sumber daya pada sisi input untuk memilih bahan yang paling efisien untuk pengembangan produk, menerapkan fleksibilitas sumber daya dan koordinasi untuk mengoptimalkan dan efisiensi pemrosesan internal, menerapkan fleksibilitas sumber daya dan koordinasi pada distribusi output untuk memperluas pasar dan menerapkan fleksibilitas koordinasi untuk merespon kondisi eksternal. Namun, menerapkan strategi fleksibilitas merespon eksternal ditemukan paling tepat untuk mengadaptasikan pembiayaan komoditas pertanian sistem resi gudang pada lingkungan.
\end{abstract}

Kata kunci: komoditas pertanian, kendala pembiayaan, strategi fleksibilitas, sistem resi gudang

${ }^{1}$ Corresponding author:

Email: max.siadari@yahoo.com 


\section{INTRODUCTION}

Agricultural commodity financing is a type of financing product that is suitably developed in the agricultural sector which needs financing to support farming activities. Financing of agricultural commodities in a warehouse receipt system empirically provides benefits and overcomes the classic funding constraint, especially for small and micro-sized businesses with weak credibility due to, for example, collateral and liquidity issues. However, it is rational for commodity financing to be developed in a structured finance way that makes crops eligible to be used as collateral and source of repayment (MacNamara, 2001; Miranda et al. 2017). In a structured commodity financing with warehouse receipts system, commodity goods are used as a guarantee and source of repayment of financing. As consequence, its financing model includes uncertain elements such as commodity price volatility, market condition and quality depreciation due to storage time as inherent factors of commodity financing. It has become the uniqueness of commodity financing that dynamic risks are taken into account as a factor in the development of the financing structure. The characteristics of warehouse receipt financing, as mentioned above, become a necessary aspect to consider when applying warehouse receipt financing in a few countries (Rutten, 2015).

Financing of agricultural commodities with warehouse receipt system has been going on for a long time in Indonesia. There are two kinds of warehouse receipt systems applied for financing. Warehouse receipt system that is developed under tripartite agreement commonly been known since 1978 as Collateral Management Agreement (CMA) and warehouse receipt system that is regulated by national regulation which known as Sistem Resi Gudang (SRG). Both systems have similar uses applicable for financing instruments. However, the regulated SRG just started in 2006. Since then the use of warehouse receipt systems has not been able to function optimally and has stagnated. Some studies on the financing of warehouse receipts have not been done significantly. Several studies are more on the implementation of warehouse receipt systems as inventory management such as. Suryani et al. (2014) stated that the benefits of using the warehouse receipt system do not conform to the conceptual model. Ashari (2012) stated that institutional bureaucratic problems hinder the system's growth. Bustamin (2014); Gunawan et al. (2019) stated that the lack of information and knowledge of warehouse receipt systems has caused the low awareness of the system. The study above has not discussed the financing issues. However, in the conceptual theory, the system is providing benefits to increase financing accessibility, especially to agricultural farmers. Several research sources from other countries, known same factors that barriers warehouse receipt system and its financing to develop such as Onumah (2010) in Malawi, identified product value, infrastructure, institutions, regulations, knowledge, expertise, commitment and trust as the key factors in developing warehouse receipt financing. Gashayie A and Singh (2015) in India identified political factors, legality, operational systems, infrastructure and technology supporting value chain systems as essential components for warehouse receipt financing. Katunze et al. (2017) in Africa stated that commodity prices are an essential factor to develop warehouse receipt financing.

The issues as identified above theoretically can be seen as product value, market attributes and information issues. On the product side, a mismatch can arise because the product does not match the value characteristics required by society (Kohler, 2009); product attribution occurs in connection with marketing and distribution problems (Becchetti and Conzo, 2009); information asymmetry causes knowledge problems (Sheth and Sisodia, 2012; Capacio, 2018) and recently the issue of changes in environmental conditions. Such problematic situations can theoretically lead to incompatibility of the product with its market situation. The Incompatibility is contributed by multi-sources of factors like internal and external changes. Internal changes trigger withininternal while external changes are triggered by external such as changes in market environment like globalization. The problematic situation and as stated theoretically can be solved with the capability of flexibility strategy within the fiancing system of agriculture commodity in warehouse receipt system.

There had been much literature on flexibility strategy (Brozovic, 2018). The flexibility strategy is not new. In the early 1970s, Ansoff had emphasized the importance of a flexibility strategy that organizations or companies need to deal more flexibly with changing environments. However, flexibility strategy should be used selectively. According to several studies, determination of the flexibility strategy should be done through an analysis process on characteristics and environment of the problematic situation. Nordin and Kowalkowrski (2010) 
stated the dimensional factors to determine flexibility strategy by identifying triggers, drivers, constraints and process and performance measurement. However, Sanchez (1995) stated strategies should be carried out with appropriate considerations distinguished for simplicity as resource flexibility and coordinating flexibility.

In order to overcome the above problems and supported by theory and literature reviews, this study aims to determine the appropriate model of flexibility strategy applied to agricultural commodities financing system in warehouse receipt system to Indonesian conditions which are empirically when applying to commodities such as coffee, pepper, rice and maize. The previous research was discussed warehouse receipts system on inventory management, while this study emphasizing the use of warehouse receipts system financing as means to increase financing accessibility (IFC, 2015). The constraints in the system conceptually can be solved with appropriate flexibility strategy model to adapt the agricultural commodities financing in a warehouse receipt system to Indonesian conditions. This study is partially preceded by several studies like characterizing the factors of the warehouse receipt financing system which is acceptable according to Indonesia condition (Sindari, 2021a), literature review of flexibility strategy to minimize gaps (Siadari, 2021b) and the extension determining the main problems and ultimately building a model for improving the warehouse receipt financing system by applying a flexibility strategy. The flexibility strategy, in this study takes statistical analysis, Soft System Methodology (SSM) and Interpretive Structural Modeling (ISM) as analysis models to describe problems and build conceptual models to adapt the warehouse financing system to its environment.

\section{METHODS}

The identification of problems in warehouse receipt financing system was performed in several districts province of Indonesia. Data was collected from August 2019 to January 2020 from participants who had knowledge of and experience in warehouse receipt financing on agricultural commodities such as coffee, pepper, maize and rice. In a purposive sampling found 40 acceptable respondents that meet the criteria were grouped into groups as follows. First, groups of farmers or farmer cooperatives such as Koperasi Mukti Niaga (Cianjur, West Java), Mitra Desa Cisuka (Tasikmalaya,
West Java), KSU Annisa (Subang, West Java), KSU Sarana Hidup Sejahtera (Grobogan, Central Java), Koperasi Kelompok Usaha Serbajadi (Natar, Lampung) and KUD Sepakat (Candipuro, Lampung) and Ketiara (Takengon, Aceh). Second, collectors or traders of agricultural commodities such as coffee, pepper, maize and rice and have experience applied commodity financing in warehouse receipt system such as Sinar Uni Grain (Surabaya, East Java) and Inensunan Mills (Bantaeng, South Sulawesi), Indra brother (Tanjung Karang, Lampung), Multi Organik Intenasioal and Putrabali Adyamulia (Tanjung Karang, Lampung) and Sarimakmur Tunggal Mandiri (Medan, North Sumatra), Third, from institutional financing whose has personnel with experience in financing commodities within warehouse receipt systems, these groups include former Rabobank Indonesia, Deuche Bank, Standard Charter Bank, CIMB Niaga, Bank Danamon, Bank Rakyat Indonesia and Bank BPD Jabar. Fourth, supporting institutions such as warehouse management, collateral management, registration office and insurance, these institutions include Bhanda Ghara Reksa, Sucofindo, Kliring Berjangka Jakarta and Insurance. Meanwhile, respondents to the research of flexibility strategy model as part of developing conceptual solution model was selecting 6 respondents of experts who know about financing agricultural commodities with warehouse receipt like traders, banker, regulator and academics.

The type of data used in this study consists of primary data and secondary data. Primary data took the form of qualitative data obtained through a survey using in-depth interviews and focus group discussion with respondents selected through targeted respondents. In addition, secondary data is obtained from various representative sources that can provide information related to the commodity warehouse receipt financing system.

The use of Soft System Methodology (Checkland, 1999) is based on the following assumptions: problems in research are unclear or messy and do not stand alone, the interpretation of stakeholder problems varies according to their perspectives, human factors play an important role, using a creative approach and intuition to solve problems and the results are more and better understanding and learning. The application of the SSM method to design systems and achieve the objectives of this research has characteristics including First, situational analysis, social analysis and political analysis (Checkland and Poulter, 2006) to determine 
stakeholder problems related to commodity financing through warehouse receipt systems in Indonesia. Second, SSM has characteristics of systematic learning orientation, rooted in the complexity paradigm, based on the views that the system can be explored, is an internal construction, intellectual and that there is a social analysis with a sustainable nature and high involvement of the human factor in research and in answering questions about what and how it is suitable for complex and unstructured problems. Third, SSM does not limit the problem to certain variables: SSM identifies as many aspects (variables) that interact in the system as possible so that the problem definition is more complete and takes into account many aspects that can anticipate the dynamics that occur. To reveal the problems that arise through Soft System Methodology (Checkland, 1999), seven steps are taken, including:

1. Description of the problem situation in order to start recognizing the problem. Problems are referred to as problem situations because problems need to be identified and resolved.

2. Expression, which includes the process of collecting data and information by conducting observations, interviews and discussions, followed by formulating and presenting these problems cast in the form of a rich picture diagram, which sketches the real problem situation in a large rich picture diagram in a helicopter view.

3. Definition of relevant systems, meaning the collection of keywords to be defined in a textual and concise business process flow. The root definition is mapped into CATWOE (Client, Actor, Transformations, World view, Owner and Environment) elements. Linking the problem to the existing system, followed by creating root definitions describing the process and transformation steps to achieve the goal (do X, through $\mathrm{Y}$, to achieve Z), after which the root definitions are tested by CATWOE analysis. $\mathrm{C}=$ Customers, the beneficiaries of T. A = Actors, those who do $\mathrm{T}$. $\mathrm{T}=$ Transformations input-output. $\mathrm{W}=$ Worldview that makes the $\mathrm{T}$ meaningful in context. $\mathrm{O}=$ Owners, those with the power to stop T. $\mathrm{E}=$ Environmental elements outside the system that become constraints on the system.

4. Creating conceptual system models based on realworld root definitions and making a conceptual system model for each system, the model is described as an activity model, followed by determining the performance measure of the model.

5. Comparisons to reality, i.e. comparing models to real situations or comparing conceptual models to reality to generate new ideas for change.

6. Discussing changes and adjustments, where together with stakeholders the determination associated with the formulation and the results of the previous stages are discussed, where the results are changes and these changes should be systematic (both means and objectives) and feasible, for example through Interpretive Structural Model (ISM) as a modeling technique developed for strategic model planning.

7. Creating improvement strategies and solutions for the recommended system with regard to taking action, at this stage for implementing recommendations using the ISM for structural modeling.

Interpretive structural modeling is used in this study in the advanced process of SSM which was developed to make the basic formation model clearer and more focused. ISM is chosen based on several assumptions. It is a modeling technique developed for strategic policy planning created by J.Warfield in 1973 as a methodology for structuring relationships between specific items in order to determine the hierarchy of relationships between subject matter and subproblems or complex systems and subproblems. ISM is a simple system and provides a fundamental understanding of the complexity of the problem and formulates a design model to solve problems and formulate business strategies or strategic policies that are operational (Fadhil et al. 2018). ISM analyzes system elements and resolves them in graphical form from the direct relationships between elements, idea categories, influence structures, priority structures and hierarchical levels (Attri et al. 2013). For the research on commodity financing warehouse receipt systems, ISM offers a concept for an alternative development model by capturing ideas from organizations composed of people who understand or have expertise in the field of study. From the discussions, several ideas or variables were obtained which were processed using ISM and developed hierarchically to execute a structured model as shown in the following steps.

1. Identify priority elements and sub-elements through in-depth interviews with several research experts

2. Formulate contextual relationships between the elements that are established using Matrix's Structural Self Interaction (SSIM matrix). Relationshipassessmentis carried out with contextual relationships with matrix pair comparisons using the symbols $\mathrm{V}, \mathrm{A}, \mathrm{X}$ and $\mathrm{O}$ with the value of: $\mathrm{V}$ if eij $=1$ and eji $=0 ; \mathrm{A}$ if eij $=0$ and eji $=1 ; \mathrm{X}$ if eij $=1$ 
and $\mathrm{eji}=1 ; \mathrm{O}$ if eij $=0$ and $\mathrm{eji}=0$.

3. Converting the SSIM matrix into a reachability matrix (RM) and then a binary matrix. This step is a process of interpreting $\mathrm{V}, \mathrm{A}, \mathrm{X}$ and $\mathrm{O}$ into numbers 1 and 0 and then corrected further connecting them in a closed-loop matrix connected to the transitivity rule that makes up the completeness of the causal loop with logic in the form of if A affects B, B affects $\mathrm{C}$, then $\mathrm{A}$ (should) affect $\mathrm{C}$ and if $\mathrm{D}$ increases $\mathrm{E}, \mathrm{E}$ increases $\mathrm{F}$, then $\mathrm{D}$ shouldn't decrease $\mathrm{F}$.

4. Performing the reachability matrix to obtain propulsion and dependability. This matrix complies with the transitivity rule and can be advanced to the partition level.

5. Formulating a canonical matrix, which is a group of elements on the same level. Canonical matrix is done by adjusting the variables to the level generated from the partition level in the form of the final reachability matrix table.

6. Applying a MICMAC analysis (from Matrices d'Impacts Croisés Multiplication Appliquée à encasement or cross-impact matrix multiplication applied to classification), abbreviated as MICMAC, an analysis used to analyze the driving force and dependability of a variable so that the results of the analysis are identified as key variables in the system. MICMAC analysis variables were developed in four sectors, as shown in Figure 1.

Assessment classification using the ISM Cartesian diagram is carried out based on a study of the DriverPower(DP) value and the Dependence (D) value in order to find the element classification. The classification of these elements is divided into four sectors, namely:

i. Sector I: Weak driver-weak dependent variables (Autonomous). The sub-elements entering this sector are generally unrelated to the system and may have few links, although these links can be strong;

ii. Sector II: Weak drivers-strongly dependent variables (Dependent). In general, the sub-elements entering this sector are sub-elements that are not free;

iii. Sector III: Strong driver-strongly dependent variables (Linkage). The sub-element entering this sector must be carefully studied, as the relationship between the sub-elements is not stable. Any action on a sub-element will have an impact on other subelements and the effect of the feedback can amplify the impact; iv. Sector IV: Strong driver-weak dependent variables (Independent). The sub-elements entering this sector are the remaining parts of the system and are called free changers.

The problem constraints on service products that were referenced to the environmental situation as described above theoretically include product values, product attributes and information asymmetry carried out in the different interests of the stakeholder. The existence of problems creates gaps in acceptability between stakeholders. The gaps between stakeholders environment that is driving from supply-side and demand-side in financing services is conceptually becoming areas of flexibility strategy as defined in Figure 2.

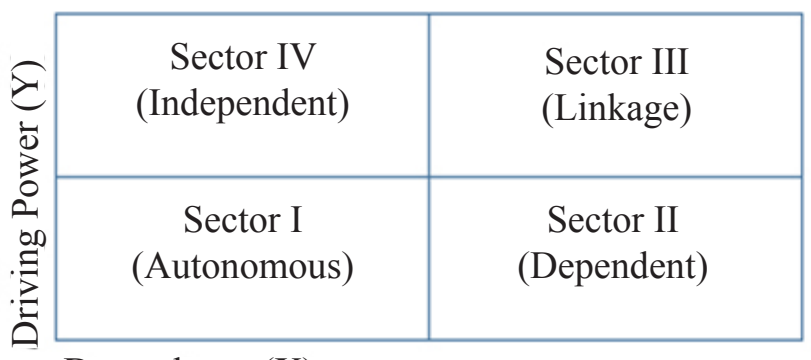

Dependence (X)

Figure 1. MICMAC analysis (Mudgal et al. 2009)

Financing Services - (Supply Side: Financing Sources and its supporting institutions)

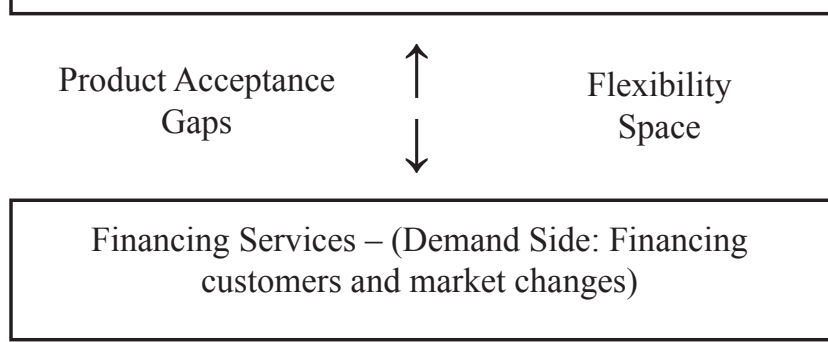

Figure 2. Distance of interest in financing product (own concept) 


\section{RESULTS}

\section{Determination of Problem Situation}

Stakeholder Analysis (SHA)

Stakeholders of agricultural commodity financing on system of warehouse receipts include: farmer groups or farmer cooperatives that produce agricultural commodities use the warehouse receipt system to manage commodity stocks and at the same time can use it as means for financing purposes; commodity collectors or traders as extended commodity owners after farmers, either by self-producing or purchasing commodities from farmers and storing them in warehouses, using warehouse receipt systems to obtain financing to improve cash flow or to meet the need for working capital; the group of financing source institutions such as the bank as a provider of financing services that use the warehouse receipt system as one of the bases to develop financing products, it was made possible by using warehouse receipts as a commercial document and as proof of existing commodities as collateral; supporting institutions such as collateral managers, warehouse operators, registration offices, insurance companies provide some kind of services to enabler warehouse receipt system financing may work.

\section{Situational Analysis}

Situational analysis includes an analysis of the environment of commodity financing. The analysis of relationships between and the roles of related parties (stakeholders) including the social and political roles in conducting activities of commodity financing on warehouse receipt system environment. These activities include activities of supplying commodities, warehousing of commodities, storage management systems or collateral management system, commodities maintenance, transportation and logistics, publishing warehouse receipts, indemnification, process of financing, trading of collateralized commodities and some other activities which are involving various parties. The environment of agricultural commodities in a warehouse receipt financing system includes stakeholders as illustrated in Figure 3. First, in the outer sector, it includes the regulatory provisions or authority of regulators for the financing system.

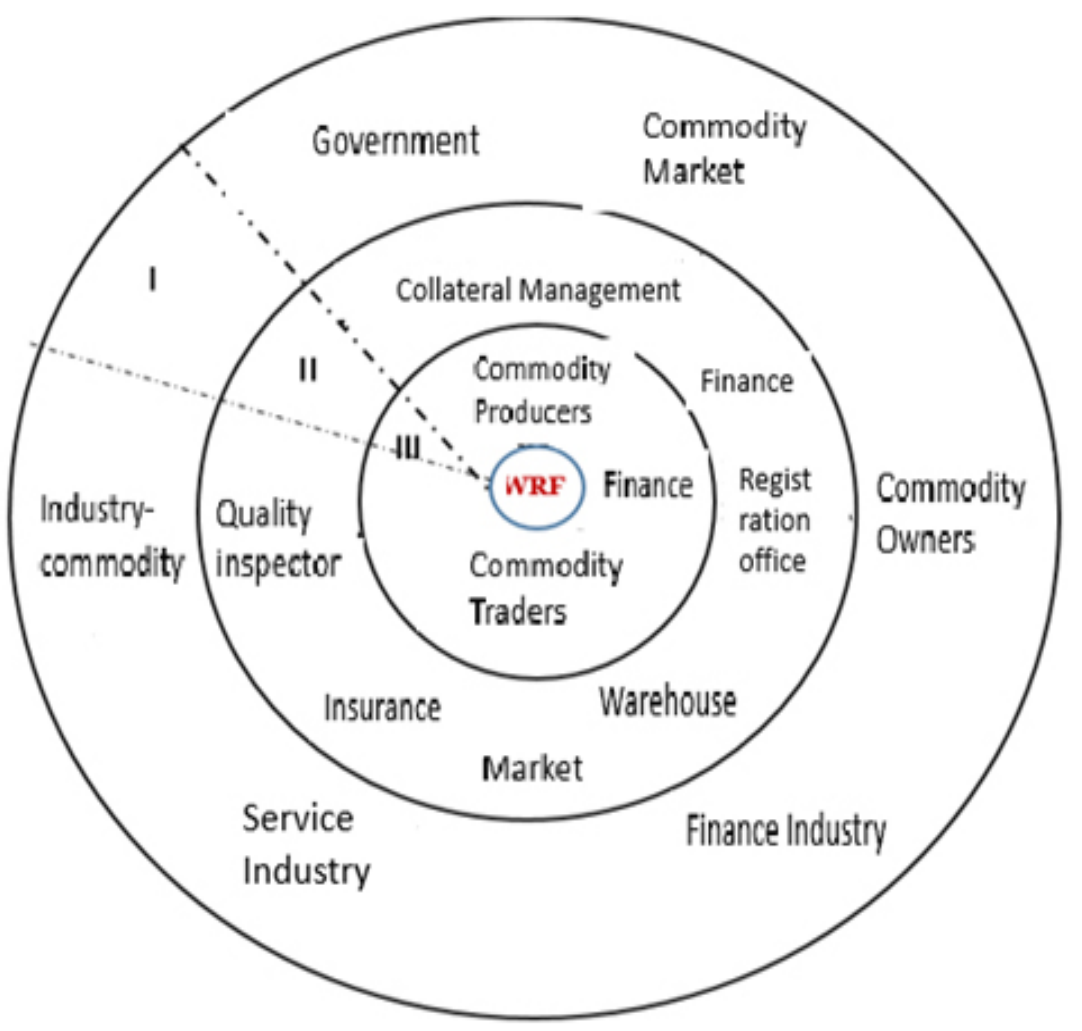

Figure 3. Environment of warehouse receipt commodity financing system 
The government plays an important role in providing policies to make a legal implementation of underlying asset when used in financing system. The government play its role in many areas for example by commodity futures trading supervisory agency said as Badan Pengawas Perdagangan Berjangka Komoditi (BAPPEBTI) to oversee the implantations of regulated warehouse receipt system and by financial services authority said as Otoritas Jasa Keuangan (OJK) to oversee financing service activities. The role of the government is expressed in policy, supervision and monitoring. Farmer communities are in the upstream part playing an important role in ensuring the sustainability of the commodity supply. Market players such as traders or collectors and business integrators and industrial communities in their role making market attractive. These supply chains and markets affect the liquidity of commodities and enable financing by the financier institutions. Other related industrial environments, such as warehousing, management services, insurance and logistics, may also affect the functioning of the warehouse receipt financing system.

Second, the industrial environment related to the financing of agricultural commodities through the warehouse receipt system directly affects commodity financing system, such as the warehousing service industry in the context of providing warehousing and its facilities for storage of commodities in secure locations; collateral management service enables control of collateralized commodities to financial institutions as recipients of guarantees; market players such as commodity markets in local or international like Bursa Berjangka Jakarta (BBJ) and Chicago Board Of Trade (CBOT); traders or collectors as aggregator companies and industries that process agricultural commodities playing important in driving commodities market and boosting the liquidity of collateralized commodities; and other related institutions that influence the support of the financing system are insurance companies, appraisal companies and logistics companies.

Third, the consumer of commodity financing services such as farmers and commodity traders. All associated parties as above in this study are connected to the warehouse receipt financing system which is theoretically built to benefit the consumers, the financing supplier and its supporting institution in a mutually beneficial. Based on the situation in Indonesia, it is deployed through a three-party contract agreement, most known as Collateral Management Agreement
(CMA) and warehouse receipt system is regulated in accordance with Law No. 9 of 2006, also referred to as the Sistem Resi Gudang (SRG).

\section{Social Analysis}

Social analysis is aimed at understanding the social situation in the implementation of the commodity financing system through warehouse receipt systems in Indonesia. This social situational description is an important consideration in formulating the solutions mentioned in stage six of the Soft System Methodology in this study. This element of social analysis includes three aspects, including roles, norms and values. These three aspects are described as follows.

Roles: the role of farmers, farmer groups, farmer group associations or farmers as a group of actors to carry out agricultural activities, ensure continuity of agricultural operational processes and produce agricultural commodities and needs financing support. The government on top management has an interest in providing a conducive environment and ensuring the smooth process of the ongoing warehouse receipt financing system. Institutions provide financing products and provide financing services to be accessible to the commodity business community. Warehouse providing institutions (either private or state) ensure the availability of warehouses and are able to accommodate agricultural products, as well as warehouse management companies and collateral managers who manage warehouses with stocks of agricultural commodities so that they allow commodities as collateral for financing. Markets (commodity markets) function as a vehicle for commodity trading to ensure the liquidity of goods. Other institutions work supportive such as insurance companies, appraisal services, fiduciary registration centers and registration centers that provide the legality for commodities as financial guarantees. Each of the aforementioned institutions plays a role in the continuity of the commodity financing system.

Norms: norms take the form of rules or regulations related to the commodity financing system or the warehouse receipt financing system. Warehouse receipt system norms are independently developed through policies or provisions related to the warehouse receipt system that are determined based on knowledge, information and regulations related to financing in the commodity financing system, although in practice these cannot always be met or perfectly executed. The 
financing agreement in the CMA or SRG system is not only influenced by regulatory provisions but also regulated by special rules that can originate from any party, for example, financial institutions, warehousing management, collateral management and warehouse receipt issuing systems, which thus also affect the operational flow of the commodity financing system.

Values: measure or standard of assessment or measurement are the basis for values, including cultural values determined by each party. Small communities in rural areas (rural residents) assess the commodity financing warehouse receipt system for the convenience it offers and for overcoming the limitations on access to financial services, unlike the commercial-scale business community that considers value through consideration of the economic value of financing. On the part of the financial and other support institutions, an assessment is made in accordance with the commercial objectives of each industry. On the other hand, the government controls the creation of a financing system that provides economic benefits and welfare for all parties.

\section{Political analysis}

Implementation of warehousereceiptsystemcommodity financing in national scope cannot be separated from the existence of roles and political interests of stakeholders that influencing their actions to the system. On the side of the farmer groups-producing community, the decision to use financing starts from the need for financing services and according to observations from farmers in Indonesia, they still position themselves as a weak group. Research among several groups of commodity-producing farmers, such as in the case of Mitra Desa Bersama Cisuka (Tasikmalaya, West Java) and Sarana Hidup Sejahtera (Grobogan, Central Java), found that commodity financing through a warehouse receipt financing system requires a major role from governments to provide financing more on social before commercial benefits (Siadari, 2021a). This is in contrast to commercial financing institutions, which have more flexibility and independence to determine financing sources and will take action according to the level of risk and the commercial goal as a tradeoff between costs and benefits. Each stakeholder's direction of interest and authority tends to move in different directions, as shown in Figure 4.

Based on the above description, the situational analysis and social and political conditions are environmental dimensions leading to triggers, enablers, barriers and operational performance options and is the objective to minimize the product gap constraints as mentioned above through implementation of the flexibility strategy in the financing of agricultural commodities, developing warehouse receipt systems using a structured analysis of Soft System Methodology and Interpretive Structure Modeling as outlined in the following sections.

\section{Determination of Flexibility Strategy Model}

Problematics of agricultural commodity financing on warehouse receipt system in Indonesia. The problems were identified by collecting data exposed by 40 specific respondents who have knowledge and experience in financing agricultural commodities. The problems are grouped base on similarities of the issues. Collected 249 items of stated issues and group in to main category as shown in Figure 5.

The problem category in the environment of stakeholder analysis as described above become problematic constraints that make gaps and conceptually makes flexibility strategy required on agricultural commodities financing. It was supported by developing a structured analysis of Soft System Methodology and Interpretive Structure Modeling as in the following sections.
Financing Customer Interest

\begin{tabular}{|c|l|}
\hline Social value-Economic value & Commercial value - economic value \\
\hline Characteristics of business nature & Risk factors (risk weight) \\
\hline Always available and accesible & Incentive of services (risk and return) \\
\hline
\end{tabular}

Figure 4. The direction of interest of demand and supply-side (Siadari, 2021b) 
Affordability to cover product risk and price Acceptability of the characeristics of product services Availability and accessibility of commodity markets Value and benefits of commodity financing products Competitiveness of product services in the market Professional collateral management Knowledge by customers about commodity financing products

Knowledge by financial intitutions abaout agricultural Bureaucracy and communication Trust in the warehouse receipt financing system Government policy Infrastructure to support the financing of waregouse receipts Availability of commodity financing products

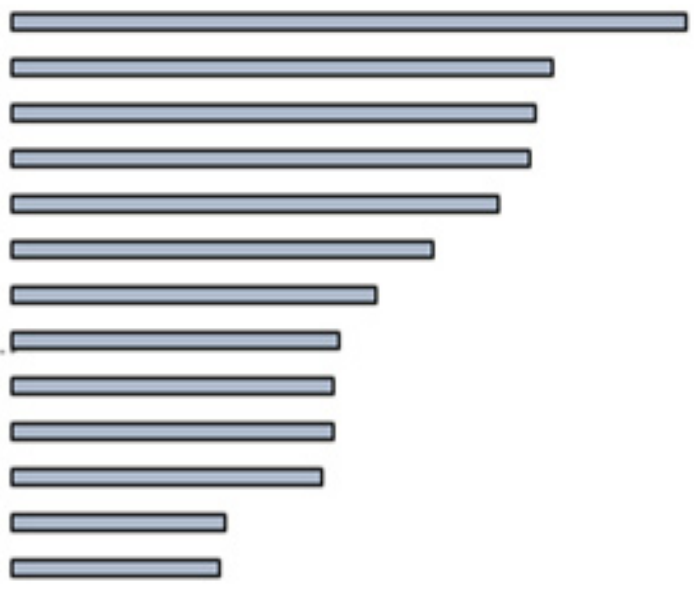

$0 \% \quad 5 \% \quad 10 \%$

Figure 5. Problem categories in financing agricultural commodities through the warehouse receipt system in Indonesia (Siadari, 2021b)

\section{Determination of the Flexibility Strategy Model}

Problem Identification

The data as shown in Figure 5 can be grouped into stakeholders: commodity producers, commodity collectors or traders, commodities financier institutions and collateral management institutions. There are 249 for mentioned items of stated issues to identify the problem. The problems are collected and classified according to the problem category into 13 groups that are used as data reference to the following steps of Soft System Methodology.

\section{Rich Picture}

The group of problems above is a source of information to describe the Rich Picture in an advanced stage of SSM. These problems include the dimensions of product value gaps, product marketing and distribution attributes and lack of information that happen in the input, process or activity and output part of the commodity financing. It is identified by service movement from one location to another (demographic consideration), from one institution or department to another or from one resource to another and is represented in the form of a rich picture in Figure 6.

A rich picture such as above portrays the constraints of financing agricultural commodities in a warehouse receipt system in Indonesia and illustrates a rather complex problem situation compared to the concept of financing theory. The warehouse receipt system for commodity financing is based on a conceptual vision that can be adopted and is perfectly applicable. But the situation faced in the real world presents a different picture with gaps between the basic concept and the reality in the real world. This is illustrated in the rich picture above using a problematic situation arrow indicating the direction of stakeholder activities interrelated with the parties in the system, such as value matters, product characteristics, management and operational systems, government policies, supporting institutions, management systems, infrastructures, information supplies, human resource capabilities and products risks and price are interconnected which becomes barriers to warehouse receipt financing system to grow.

\section{Root definition}

Root definition is a structured description of the human activity system relevant to the above problem situation. SSM determines the root definition with the PQR formula: "do P through or by $\mathrm{Q}$ to achieve R" or "do a system of doing P by Q to achieve R" or "do P, by Q, to help achieve R" (Checkland and Poulter 2006) or in a social system to determine the answers to the question of which goods or services will be produced (what), how they should be produced (how) and for whom (for whom) those goods or services will be produced. The $\mathrm{PQR}$ results were analyzed using the CATWOE step to determine the proposed model or a full activity model (PAM). Determination of the root definition and the Purposeful Activity Model took place in this study as indicated in the following section. 
Root definition: To develop agricultural commodity financing in a warehouse receipt system compatible with the environment $(\mathrm{P})$, is carried out with a flexibility strategy (Q), to active product adaptability to the environment changes $(\mathrm{R})$.

\section{Conceptual Model}

The conceptual model was developed with the idea of Fitriati's (2014) ranking system for the purpose of commodity financing, warehouse receipt systems and goal-oriented activities, as shown in Figure 7. Product development begins with establishing values to be developed according to the definition of strategy flexibility that allows for space for development by identifying the enablers and barriers to running the system, determining the type of strategy by means of available options, transforming the system using flexibility options in accordance with the vision that makes the flexibility strategy to executing a flexible strategy process, performance measurement, executing a strategy of continuous flexibility and managing risk and deviation of the strategy.

Comparing conceptual model and real words

Comparison between conceptual models and real world. These differences provide the dimensional elements of flexibility strategy to be applied in agricultural commodity financing with warehouse receipt system. Its shows the comparison of the output of real-world activity and theoretical references that explaining the element of flexibility strategy as shown in Table 1.

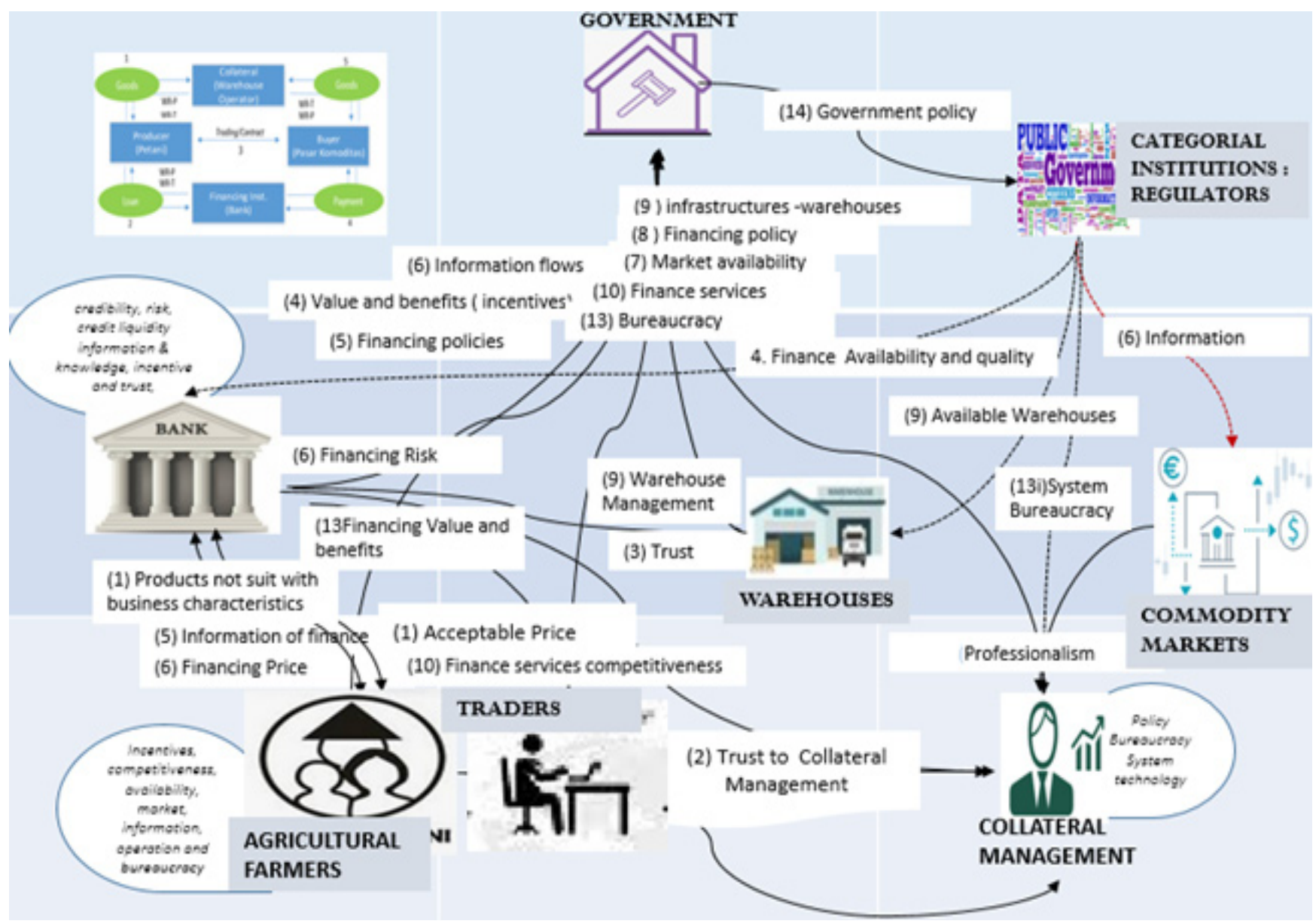

Figure 6. Rich picture of problematic warehouse receipt financing system 


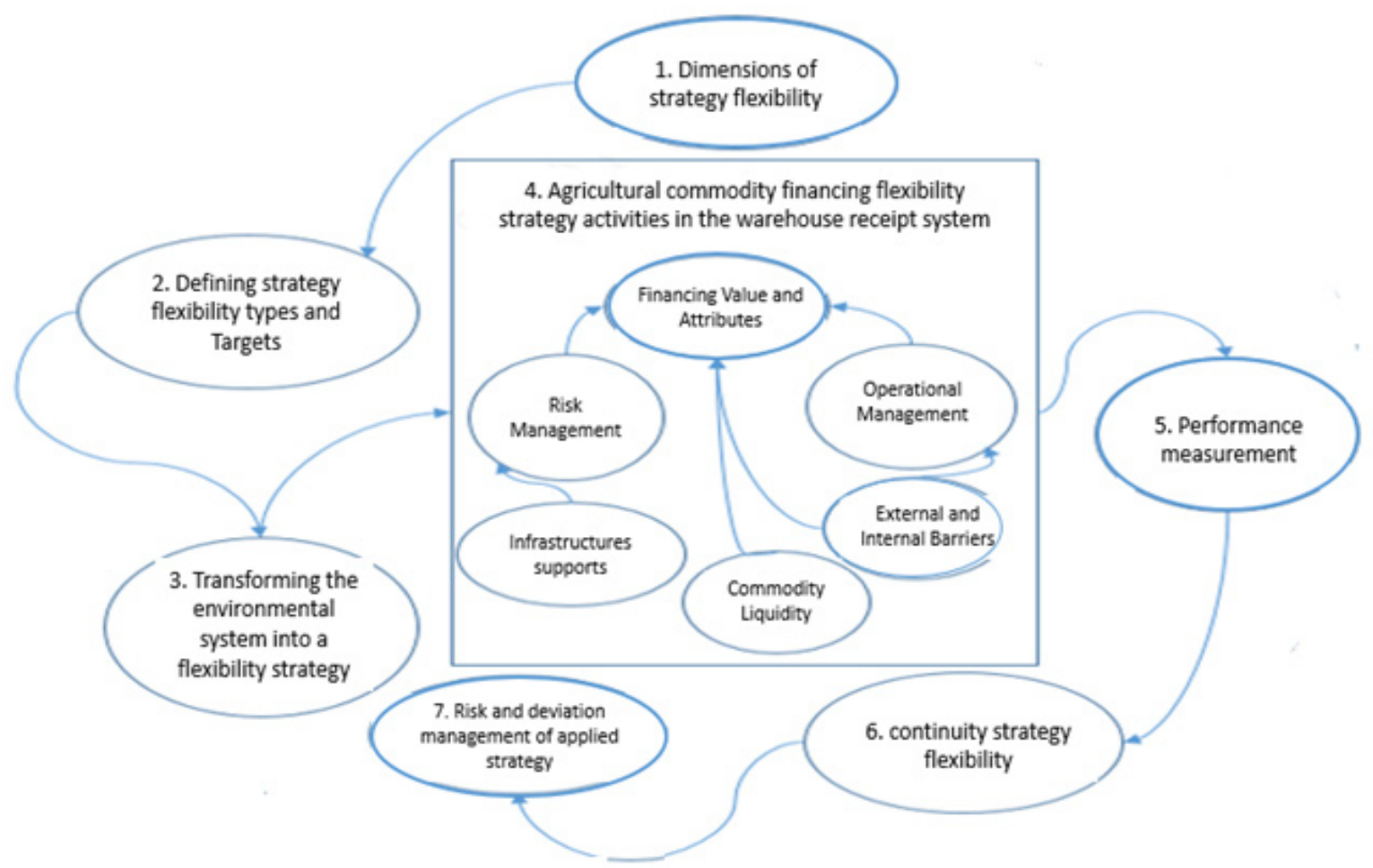

Figure 7. The conceptual model of flexibility strategy as applied in the warehouse receipt financing system

Table 1. Comparison of the conceptual model of flexibility strategy (FS) and real world*

\begin{tabular}{|c|c|c|c|}
\hline Conceptual Model of FS & $\begin{array}{l}\text { Description of real-world } \\
\text { activities }\end{array}$ & Output of real-world activity & Theoretical references \\
\hline $\begin{array}{l}\text { Determining driving } \\
\text { factors of FS }\end{array}$ & $\begin{array}{l}\text { Various characteristics of } \\
\text { changes }\end{array}$ & $\begin{array}{l}\text { Adaptation to the value in } \\
\text { according to environment }\end{array}$ & $\begin{array}{l}\text { Nordin and Kowalkowrski } \\
\text { (2010); Gashayie and Singh } \\
\text { (2015). }\end{array}$ \\
\hline $\begin{array}{l}\text { Determining triggers } \\
\text { factor of FS }\end{array}$ & $\begin{array}{l}\text { Trigger factor should be } \\
\text { clearly defined }\end{array}$ & Cause and effect identified & $\begin{array}{l}\text { Nordin and Kowalkowrski } \\
(2010)\end{array}$ \\
\hline $\begin{array}{l}\text { Determining enablers } \\
\text { of FS }\end{array}$ & $\begin{array}{l}\text { Multi factors as determinant } \\
\text { factors to enable FS }\end{array}$ & $\begin{array}{l}\text { Enablers i.e.: culture, } \\
\text { organization, finance, } \\
\text { technology, and knowledge }\end{array}$ & $\begin{array}{l}\text { Ouakouak and Ammar } \\
\text { (2014), deSoto-Camacho and } \\
\text { Vargas-S' } \text { 'anchez (2015). }\end{array}$ \\
\hline $\begin{array}{l}\text { Determining Barriers } \\
\text { of FS }\end{array}$ & $\begin{array}{l}\text { Constraints may be various } \\
\text { according to the environment } \\
\text { conditions }\end{array}$ & $\begin{array}{l}\text { Constrain of FS i.e.: Culture, } \\
\text { rigid organization, limited } \\
\text { resources and finance and } \\
\text { knowledge }\end{array}$ & $\begin{array}{l}\text { Ouakouak and Ammar } \\
\text { (2014), deSoto-Camacho and } \\
\text { Vargas-S'anchez (2015), Lin } \\
\text { dan Wu, (2014). }\end{array}$ \\
\hline $\begin{array}{l}\text { Determining } \\
\text { management process } \\
\text { of FS }\end{array}$ & $\begin{array}{l}\text { Process must be suitable with } \\
\text { the room of FS }\end{array}$ & $\begin{array}{l}\text { Suiting the process } \\
\text { improvement to problem } \\
\text { dimensions. }\end{array}$ & $\begin{array}{l}\text { Variations in product, system, } \\
\text { operational, management } \\
\text { constraints (Capacio et al. } \\
\text { 2018); Stiglitz and Weiss } \\
\text { 1981). }\end{array}$ \\
\hline $\begin{array}{l}\text { Determining areas of } \\
\text { implementation of FS }\end{array}$ & $\begin{array}{l}\text { The objectives of } \\
\text { implementing the flexibility } \\
\text { strategy are determined by the } \\
\text { company }\end{array}$ & $\begin{array}{l}\text { While FS apply in to the } \\
\text { system, it might in whole } \\
\text { parts of system. }\end{array}$ & $\begin{array}{l}\text { Room of constraints and } \\
\text { flexibility strategy (Sheth and } \\
\text { Sisodia 2012, Sushil 2005) }\end{array}$ \\
\hline $\begin{array}{l}\text { Determining Option of } \\
\text { FS }\end{array}$ & $\begin{array}{l}\text { The flexibility strategy type } \\
\text { must be based on the problems } \\
\text { situation }\end{array}$ & $\begin{array}{l}\text { FS through resource flexibility } \\
\text { or coordination flexibility }\end{array}$ & $\begin{array}{l}\text { Resources flexibility and } \\
\text { coordinating flexibility. } \\
\text { Sanchez (1995). }\end{array}$ \\
\hline $\begin{array}{l}\text { Determining } \\
\text { measurement } \\
\text { performance of FS }\end{array}$ & $\begin{array}{l}\text { There are multi criteria to } \\
\text { measure a success FS }\end{array}$ & $\begin{array}{l}\text { Measurements for example: } \\
\text { aspects of time, cost, and } \\
\text { value added. }\end{array}$ & $\begin{array}{l}\text { Sheth and Sisodia (2012), Li } \\
\text { et al., } 2016\end{array}$ \\
\hline
\end{tabular}


Changes systemically desirable and culturally feasible - Activity with strategy

At this stage, the difference between the conceptual model and the real world determines the transformation or change that is systematically and culturally appropriate designed and aimed at improvement. Changing activities in this study are supported by the availability of implementation space for flexibility to use internal and external resources in a financing systems environment that is run with resource flexibility and coordinating flexibility to minimize constraints and optimize system performance.

\section{Debate about Change}

Availability of flexibility strategy as options supported by available element was tested with experts who have knowledge on ISM and having understanding about commodity financing in a warehouse receipt systems. Determining the main key factor from the various alternatives and debated with experts to get the best choice in the implementation of flexibility strategy into the system. Using Interpretive Structure Modeling to analysis data generated from focus group discussions which are designed in a structured way to obtain opinion from selected expertise from the following institution: trade expert from minister of trading who understands the SRG system, expert from the ministry of food and agriculture, expert from collateral management or superintendent company and expert from academics. The collected data processing to get the result for the elements and sub-elements which are grouped and processed based on by following elements such as environmental factor (forces, triggers, support, barriers, activity process), selecting flexibility type, area of transformation and goals to be achieved, rooms of implementation and measurement of performance or effectiveness which are arranged in structured elements (Saxena, 1992). The element of flexibility strategy is developed with available options to ease the expert expressing their judgment. Based on the input and processing using ISM technique the implementation of flexibility strategy on agricultural commodities financing with warehouse receipt system may be developed with the elements and sub-element as shown in Table 2.

\section{Determination of Space for the Implementation of the Flexibility Strategy}

Based on the dimensions of the above flexibility strategy, the implementation of a flexibility strategy on the warehouse receipt financing system in order to minimize system constraints with its environment is determined using Interpretive Structure Modeling (Saxena, 1992). The environmental elements that determine the areas of flexibility strategy can be developed in the input, process, output and respond feedback sections on the view of the system, as shown in Table 3.

The four sections as above as the room of implementations of flexibility strategy on agricultural commodity financing on this study has been tested with the expert. The data analysis using interpretive Structure Modeling. The implementation of flexibility strategy to responded external feedbacks is becoming the most important that was applicable on several area of flexibility such as coordinating flexibility on defining and build products value, methods, system bureaucracy and communication, policies, infrastructures, operation system, risk management, information supplies and knowledge that are suitable with environmental conditions. However, Based on data analysis using ISM the elements of strategy flexibility to respond external are known that flexibility strategy to determine value and benefits of product to match with market demand is the most used drivers. Through the flexibility strategy to respond, companies can allocate product goals to economic goals, social goals and even for environmental preservation in a way to develop sustainable products. Another sub-element is the fulfilment of human resource capabilities, which can be overcome by coordinating internal and external resources. Likewise, by overcoming restrictions, such as in the sub-elements, minimizing restrictions on policies, provisions that are required by external parties that prevent the product or system from developing. The flexibility of external coordination opens access for stakeholders to complement each other. Other sub-elements such as government policies and the bureaucratic system are elements of problems that can be minimized by performing coordination within stakeholders the warehouse receipt financing system environment. The matrix of the ISM as priority element of implementing flexibility strategy on agricultural commodity financing with warehouse receipt financing system is illustrated in Figure 8. 
Table 2. Matrix of the ISM Technique and priority element of the flexibility strategy

\begin{tabular}{|c|c|}
\hline Element of FS & Main Element and MICMAC analysis- Priority FS \\
\hline Setting goals of FS & Change in Value $(*)$ \\
\hline Environment supporter (enablers) & Government agencies and financing services $(*)$ \\
\hline Triggers of FS (Triggers) & Financing Accessibility $(*)$ \\
\hline Barriers to implementing flexibility strategies (Barriers) & Characteristics of a rigid organization $(*)$ \\
\hline Flexibility strategy objectives & Improve accessibility $(*)$ \\
\hline $\begin{array}{l}\text { Room of flexibility strategy applied on the WRF } \\
\text { (Selecting process of flexibility) }\end{array}$ & Flexibility to respond to environmental conditions $(*)$ \\
\hline Measurement of achievement (Time, Cost, Volume) & $\begin{array}{l}\text { Period of products available in market and volumes of } \\
\text { products used by customers }(*)\end{array}$ \\
\hline Actors Organization or Institutions & Government $(*)$ \\
\hline
\end{tabular}

*Strong driving power and independent factors to lead strategy flexibility.

Table 3. Activities of the flexibility strategy in warehouse receipt financing system

\begin{tabular}{|c|c|c|}
\hline Area of FS & Activity of flexibility strategy & Flexibility type \\
\hline Select input & $\begin{array}{l}\text { - Selecting type of commodity (criteria, type \& quality) } \\
\text { - Selecting type financing (schemes, terms and price) } \\
\text { - Selecting method of warehouse receipt ( CMA or SRG or its combination) } \\
\text { - Selecting infrastructure to be used (private or gov.) } \\
\text { - Selecting market reference (local and international) } \\
\text { - Selecting standard and information feeders } \\
\text { - Selecting price references ( local or international) } \\
\text { - Selecting people to control ( internal and external) } \\
\text { - Etc. }\end{array}$ & $\begin{array}{l}\text { Resource } \\
\text { flexibility } \\
\text { within internal } \\
\text { resources }\end{array}$ \\
\hline $\begin{array}{l}\text { Optimizing internal } \\
\text { process }\end{array}$ & $\begin{array}{l}\text { - Flexibility in internal regulation } \\
\text { - Flexibility in coordinating } \\
\text { - Flexibility in internal bureaucracy } \\
\text { - Flexibility in organization } \\
\text { - Flexibility in path of process handling } \\
\text { - Flexibility in operational cooperating } \\
\text { - Flexibility in selecting and using human resources } \\
\text { - Etc. }\end{array}$ & $\begin{array}{l}\text { Resources and } \\
\text { coordination } \\
\text { flexibility } \\
\text { within internal } \\
\text { resources }\end{array}$ \\
\hline $\begin{array}{l}\text { Maximize output } \\
\text { distribution }\end{array}$ & $\begin{array}{l}\text { - Flexibility in marketing system } \\
\text { - Flexibility in distribution channels } \\
\text { - Flexibility pricing system } \\
\text { - Flexibility in information supply. } \\
\text { - Flexibility in packaging system } \\
\text { - Etc. }\end{array}$ & $\begin{array}{l}\text { Resources and } \\
\text { coordination } \\
\text { flexibility } \\
\text { within internal } \\
\text { resources }\end{array}$ \\
\hline $\begin{array}{l}\text { Minimaxing } \\
\text { external barriers }\end{array}$ & $\begin{array}{l}\text { - Cooperating to define collaborative value } \\
\text { - Cooperating to define method used } \\
\text { - Cooperating to define way of bureaucracy } \\
\text { - Cooperating to define integrated policy } \\
\text { - Cooperating to develop infrastructure } \\
\text { - Cooperating to develop operation system } \\
\text { - Cooperating to managing risk } \\
\text { - Cooperating in information sharing and supply } \\
\text { - Cooperating to build skillful human resources }\end{array}$ & $\begin{array}{l}\text { Coordination } \\
\text { flexibility } \\
\text { of internal } \\
\text { and external } \\
\text { resources }\end{array}$ \\
\hline
\end{tabular}



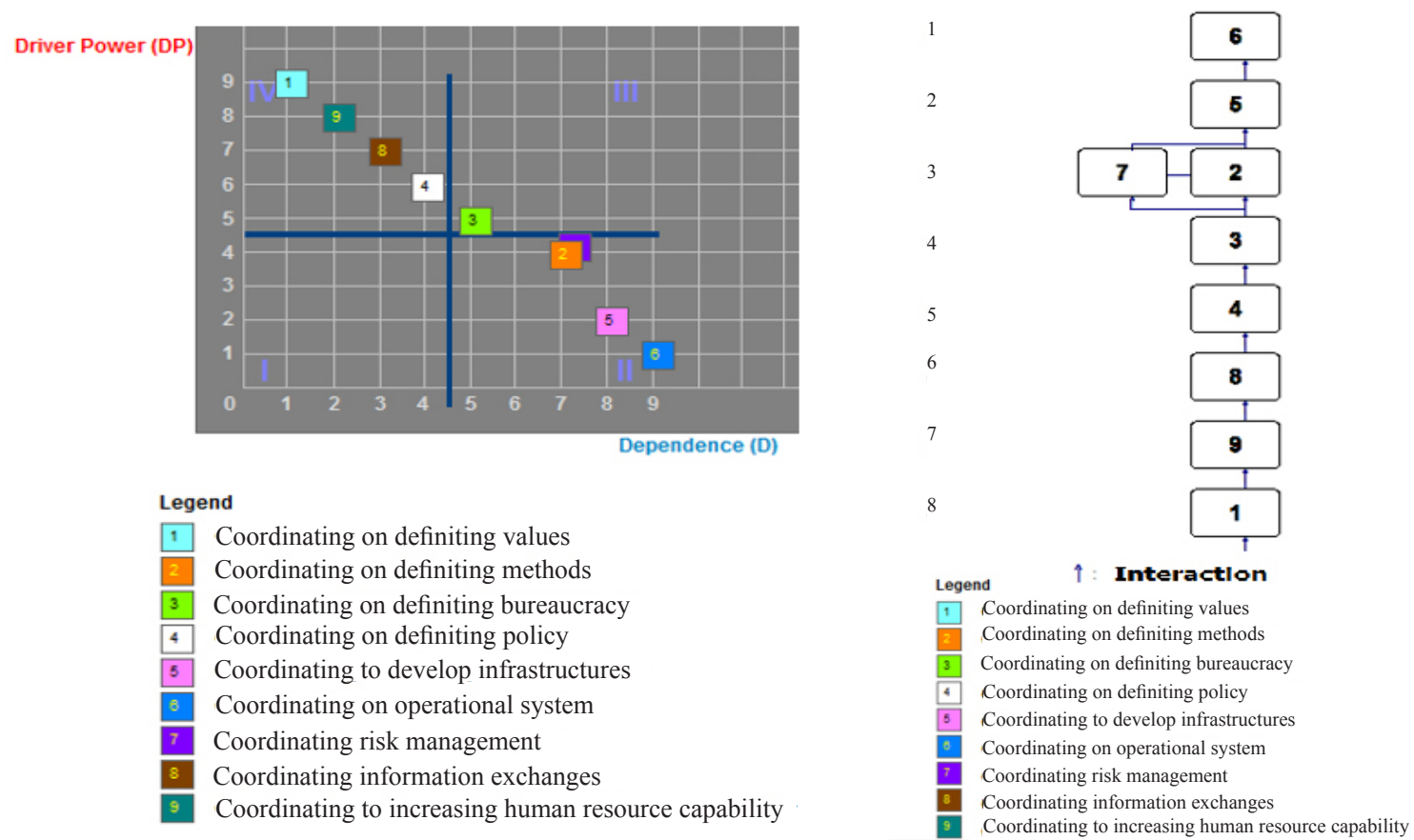

0 revised opinion and $100 \%$ consistent presentation

Figure 8. Coordinating flexibility in warehouse receipt financing system environment

\section{Managerial Implication}

Based on Soft System Methodology and Interpretive Structure Modeling to develop a conceptual model of adaptable warehouse receipt financing system using flexibility strategy. There is some important information applicable to be used in order to develop warehouse receipt financing system when applied in agriculture sectors. Flexibility strategy applicable in the input section of the warehouse receipt financing system such as flexibility in selecting type of commodity (criteria, type \& quality), selecting type financing (schemes, terms and price), selecting method of warehouse receipt (CMA or SRG or its combination), selecting infrastructure to be used (private or government facilities), selecting market reference (local and international), selecting standard and information feeders, selecting price references, selecting risk mitigations, and selecting people from external (Sanchez, 1995; Sushil, 2005). In the process section of system flexibility is applicable on such Flexibility in internal regulation flexibility in using internal resources, internal bureaucracy, dynamics organization, process path and flows, process handling, operational procedures and flexibility in using human resources within the organization ( $\mathrm{Li} \mathrm{Y}$ et al. 2016). In the output section of system flexibility is applicable for flexible marketing and distributions such as defining and selecting distribution channels, setting selling pricing, selecting marketing kits and media to information supplies and flexibility of product financing packaging like direct financing, structured financing and omnibus financing (Kurt and Hulland, 2013). And, flexibility strategy is applicable to respond external feedback to get closer the products services to the market environment demands (Li et al. 2004; Sushil, 2005; Eryesil, 2015; Pellegrino et al. 2018). However, the implementation of flexibility strategy should be made selectively and accompanied by assessment to ensure the strategy applying rightly. The wrong implementation of flexibility strategy in a system can also produce unexpected our come which by the end may raise risk to the company.

\section{CONCLUSIONS AND RECOMMENDATIONS}

\section{Conclusions}

Based on the above findings, the flexibility strategy model that is suitable to be applied on agricultural commodity financing with a warehouse receipt system are as follows: First, applying flexibility strategy on input selection (external in), for example determining structures type, type of commodity, quality of commodities, references price, method supervision and 
selecting infrastructure to use. This goal is supported by resource flexibility of the system. Second, applying flexibility strategy on process syetem, for optimization and efficiency by applying flexible organization from a rigid to flexible organization, shortages internal bureaucracy, straight through operational activities, flexible in selection and using human resource within the organization to become the most efficient. This goal can be supported by resource and coordinating flexibility. Third, applying flexibility strategy to increase product distribution or upsizing market (inout), for example, flexible distribution channels, flexible features, provisions, packaging, service time and prices. This goal can be supported by a strategy of resource flexibility and coordinating flexibility. Fourth, applying flexibility strategy to respond to external feedback that involves for example by cooperating in building shared values (economic, social, environmental), determining new improvement (methods, system, bureaucratic, system), operational cooperation, develop infrastructure, selecting technology, risk burden, information exchanges and human resources. This goal can be supported by coordinating flexibility within the stakeholder. It was also concluded by applying flexibility strategy model on responding external are most suitable to adapt agricultural commodity financing in a warehouse receipt system to its environment.

\section{Recommendations}

Based on the above findings, there are several flexibility strategy spaces that can be chosen to minimize the constraints that impede the development of agricultural commodity financing. However, this research has yet to develop into a broader study that can be related to the scope of other service products and to different environmental situations. There are various other aspects that can be studied more deeply, for example, the situational state of the product or the identification of a service system that cannot be overcome by a flexibility strategy. The development of other studies on flexibility strategies to minimize the constraints of the disparities in service products with the environment is expected to complement this research and previous research

\section{REFERENCES}

Ashari. 2012. Potensi dan Kendala Sistem Resi Gudang Untuk Mendukung Pembiayaan Usaha Pertanian di Indonesia. Bogor: Pusat Sosial Ekonomi dan Kebijakan Pertanian

Attri R, Nikhil D, Vivek S. 2013. Interpretive structural modeling (ISM) approach: An overview. Research Journal of Management Sciences 2(2):3-8.

Becchetti L, Conzo P. 2009. Creditworthiness as a signal of trustworthiness: Field experiment in microfinance and consequences on causality in impact studies. RePEc 1-62.

Brozovic D. 2018. Strategic flexibility: A review of the literature. International Journal of Management Reviews 20:3-31. https://doi.org/10.1111/ ijmr.12111.

Bustamin. 2014. Management strategy of management strategy of warehouse receipt system on coconut commodities Indonesia. Jurnal Aplikasi Manajemen 16(4):586-592. DOI:10.21776/ ub.jam.2018.016.04.04

Capacio, Emmanuel, Tulder, 2018. Breaking Barriers in Agriculture Financing: Enhancing The Inclusiveness and Sustainability of Agriculture Value Chains. Filipina: University of Philippines.

Checkland, Poulter J. 2006. Learning for Action: A Short Definitive Account of Soft System Methodology, and Its Use for Practitioners, Teachers and Student. New York: Willey.

Checkland P. 1999. System Thinking, System Practice. New York: Willey.

Eryesil K, Esmen, Beduk A. 2015. The role of strategic flexibility for achieving sustainable competition advantage and its effect on business performance. International Journal of Business and Economics Engineering 9(10).

Fadhil R, Maarif M, Bantacut T, Hermawan A.2018. Formulation for development strategy of Gayo Coffee Agroindustry Institution using Interpretive Structural Model (ISM). Acta Universities Agriculturae et Silviculturae Mendelianae Brunensis 66(2):487-495. https:// doi.org/10.11118/actaun201866020487.

Gashayie, Singh M. 2015. Agricultural Finance Constraints andInnovativeModels Experiencefor Ethiopia: Empirical Evidence from Developing Countries. India: Punjabi University.

Gunawan E, Kuwornu J, Nguyen ADLT. 2019. Farmers' Perceptions of The Warehouse Receipt System In Indonesia. Thailand: Department of Food, Agriculture, and Bio resources, School of Environment. Sustainability 11(6): 1690; https:// 
doi.org/10.3390/su11061690.

[IFC] International Finance Corporation . 2015. Warehouse finance and warehouse receipt systems: A guide for financial institutions in emerging economies. http://www.ifc.org.

Kurt D, Hulland J .2013. Aggressive marketing strategy following equity offerings and firm value: The role of relative strategic flexibility. Journal of Marketing 77:57-74. https://doi.org/10.1509/ jm.12.0078.

Li Y, Su Z, Liu Y. 2016. Fast adaptation, strategic flexibility and entrepreneurial roles. Chinese Management Studies 5(3):256 - 271. https://doi. org/10.1108/17506141111163354.

MacNamara J. 2001. Structured Trade and Commodity Finance in Emerging Market. Inggris: Woodhead Publishing Limited.

Miranda MJ, Mulangu FM, Francis H, Kemeze. 2017. Warehouse Receipt Financing for Smallholders in Developing Countries: Short on Logic, Long on Imagination. Colombus: Ohio State University.

Mudgal RK, Shankar R, Talib P, Raj T. 2009. Greening the supply chain practices: an Indian perspective of enablers' relationship'. International Journal of Advanced Operations Management 1(5):151176.

Nordin F, Kowalkowrski. 2010. Solutions offerings: A critical review and reconceptualisation. Journal of Service Management 21:441-459. https://doi. org/10.1108/09564231011066105.

Ouakouak, Ammar. 2015. How does strategic flexibility pay off in terms of financial performance. International Journal of Business
Performance Management 16:442-456. https:// doi.org/10.1504/IJBPM.2015.072241.

Pellegrino R .2018. Supply Chain Finance: A supply chain-oriented perspective to mitigate commodity risk and pricing volatility. Journal of Purchasing and Supply Management 25(2): 118-133.

Rutten L. 2015. The use of warehouse receipt finance in agriculture in transition countries, World Grain Forum 2009. https: //www.researchgate.net.

Sanchez R. 1995. Strategic flexibility in product competition. Strategic Management Journal 16:135-159.https://doi.org/10.1002/ smj.4250160921.

Siadari K, Maarif S, Arifin B, Rangkuti Z. 2021a. Characteristics of Agricultural Commodities Financing Base on Warehouse Receipt System in Indonesia. Journal of Economics and Sustainable Development 12(6): 52-61.

Siadari K, Maarif S, Arifin B, Rangkuti Z. 2021b. Indentifikasi kendala pembiayaan komoditas sistem resi gudang di Indonesia. Electronic Journal of the Ministry of Trade.

Sheth JN, Sisodia RS. 2012. The 4A's of Marketing. Creating Value for Customers, Companies and Society. New York: Routledge.

Suryani E, Erwidodo, Setiadjie I. 2014. Sistem Resi Gudanga di Indonesia Antara Harapan dan Kenyataan. Bogor: Institut Pertanian Bogor.

Sushil. 2005. A flexible strategy framework for managing continuity and change. International Journal of Global Business and Competitiveness 1(1): 22-32. 